OPEN ACCESS

Edited by:

Carmen Arena

University of Naples Federico II, Italy

Reviewed by:

Pradeep Kumar,

Central Arid Zone Research Institute

(ICAR), India

Byoung Ryong Jeong,

Gyeongsang National University,

South Korea

${ }^{*}$ Correspondence:

Paul Zabel

paul.zabel@dlr.de

Specialty section:

This article was submitted to

Plant Abiotic Stress,

a section of the journal

Frontiers in Plant Science

Received: 31 July 2019

Accepted: 28 April 2020

Published: 26 May 2020

Citation:

Zabel P, Zeidler C, Vrakking V.

Dorn M and Schubert D (2020)

Biomass Production of the EDEN ISS

Space Greenhouse in Antarctica

During the 2018 Experiment Phase.

Front. Plant Sci. 11:656.

doi: $10.3389 /$ fpls.2020.00656

\section{Biomass Production of the EDEN ISS Space Greenhouse in Antarctica During the 2018 Experiment Phase}

\author{
Paul Zabel*, Conrad Zeidler, Vincent Vrakking, Markus Dorn and Daniel Schubert \\ EDEN Research Group, German Aerospace Center (DLR), Institute of Space Systems, Bremen, Germany
}

The EDEN ISS greenhouse is a space-analog test facility near the German Neumayer III station in Antarctica. The facility is part of the project of the same name and was designed and built starting from March 2015 and eventually deployed in Antarctica in January 2018. The nominal operation of the greenhouse started on February 7th and continued until the 20th of November. The purpose of the facility is to enable multidisciplinary research on topics related to future plant cultivation on human space exploration missions. Research on food quality and safety, plant health monitoring, microbiology, system validation, human factors and horticultural sciences was conducted. Part of the latter is the determination of the biomass production of the different crops. The data on this topic is presented in this paper. During the first season 26 different crops were grown on the $12.5 \mathrm{~m}^{2}$ cultivation area of the greenhouse. A large number of crops were grown continuously throughout the 9 months of operation, but there were also crops that were only grown a few times for test purposes. The focus of this season was on growing lettuce, leafy greens and fresh vegetables. In total more than $268 \mathrm{~kg}$ of edible biomass was produced by the EDEN ISS greenhouse facility in 2018. Most of the harvest was cucumbers $(67 \mathrm{~kg})$, lettuces $(56 \mathrm{~kg})$, leafy greens $(49 \mathrm{~kg})$, and tomatoes $(50 \mathrm{~kg})$ complemented with smaller amounts of herbs $(12 \mathrm{~kg}$ ), radish (8 kg), and kohlrabi $(19 \mathrm{~kg})$. The environmental set points for the crops were 330-600 $\mu \mathrm{mol} /\left(\mathrm{m}^{2 *} \mathrm{~s}\right)$ LED light, $21^{\circ} \mathrm{C}, \sim 65 \%$ relative humidity, $1000 \mathrm{ppm}$ and the photoperiod was $17 \mathrm{~h}$ per day. The overall yearly productivity of the EDEN ISS greenhouse in 2018 was $27.4 \mathrm{~kg} / \mathrm{m}^{2}$, which is equal to $0.075 \mathrm{~kg} /\left(\mathrm{m}^{2 *} \mathrm{~d}\right)$. This paper shows in detail the data on edible and inedible biomass production of each crop grown in the EDEN ISS greenhouse in Antarctica during the 2018 season.

\footnotetext{
Keywords: bio-regenerative life support system (BLSS), plant cultivation chamber, space plant growth facility, space food and nutrition, space analog studies, controlled environment agriculture (CEA)
}

\section{INTRODUCTION}

Food production during human space missions to and on Moon and Mars is a necessary step to reduce resupply mass from Earth and thus long-term mission costs. Growing plants for food production also offers the advantages of producing oxygen and removing carbon dioxide from the atmosphere as well as the recycling of water. Because of these advantages, experiments in growing 


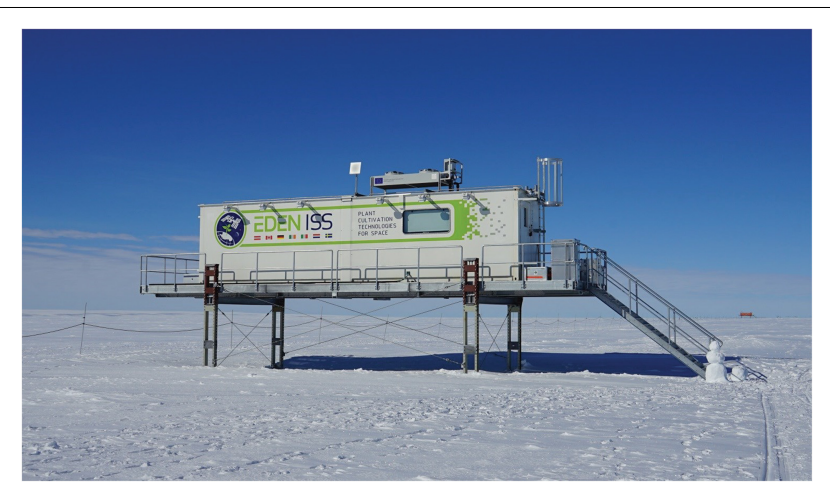

FIGURE 1 | The EDEN ISS Mobile Test Facility in Antarctica around $400 \mathrm{~m}$ south of the German Neumayer Station III.

plants in space began as early as the first manned space stations and continue to the present day (Zabel et al., 2016a).

Several research teams conducted experiments in cultivating plants in a closed controlled environment on Earth for the application in future space missions in the past (Wheeler, 2017). Notable are NASA's Biomass Production Chamber (Wheeler et al., 2003; Dreschel et al., 2018), the Russian BIOS facilities (Gitelson et al., 2003), the Japanese Closed Ecology Experimental Facility (Nitta, 2005) and the Chinese Lunar Palace 1 (Fu et al., 2016).

The EDEN ISS project is the newest space greenhouse analog project to test subsystems, technologies, operation procedures, plant health monitoring devices and plant cultivation for future space missions. The EDEN ISS Mobile Test Facility (MTF) (Figure 1) was setup in Antarctica to achieve these goals. This paper presents detailed values on food production (edible biomass) and inedible biomass production of the vegetable crops cultivated in the experimental phase in 2018.

The difference of the EDEN ISS MTF to the other facilities is its unique location. The MTF is positioned in the vicinity of the German Neumayer Station III in Antarctica. This continent offers several conditions which are favorable for space analog test campaigns (Bubenheim et al., 1994). While most of the other facilities were built to conduct research on humans living in a closed loop life support system, EDEN ISS focuses on cultivating plants in controlled conditions, testing the necessary hardware and investigating microbiology, food quality and safety aspects. Furthermore, most of the facilities mentioned earlier were built and operated in the 1980s-2000s and are no longer available, except for Lunar Palace 1 which was built only a few years ago and is still in operation. EDEN ISS also uses technologies which were not available in the past (e.g., LED lighting for plant cultivation).

The novel aspect of the EDEN ISS project is its approach to work with a compromise climate in which all crops are grown simultaneously. This is more realistic for near-term space greenhouses as compared to studies were each crop has its own optimized climate. Despite not having the optimal climate for each crop the food production of the MTF in the 2018 season was higher than expected. In 2018, for the first time a comprehensive set of measurements were performed in an analog space greenhouse. These measurements encompass the biomass production data presented in this paper, but also data on the microbial environment inside the greenhouse, the quality and safety of the produced food, the resources (e.g., carbon dioxide, nutrients, consumables) necessary to grow the crops, the amount of electrical energy and crewtime required and the acceptance of the food to the station crew. The biomass production dataset presented in this paper can be used to improve simulation models for space greenhouses. It can also be used for cultivar selection, because the dataset includes values on different cultivars (e.g., for lettuce and tomato) which is helpful to assess which cultivar should be grown in the next space greenhouse. The data is also a valuable contribution to the recently developed Crop Readiness Level evaluation method (Romeyn et al., 2019) for crop candidates for space greenhouses.

\section{MATERIALS AND METHODS}

\section{EDEN ISS Mobile Test Facility Infrastructure}

The EDEN ISS MTF is located in the immediate vicinity of the Neumayer III Station which is operated by the German AlfredWegener Institute for Polar and Marine Research. The MTF was designed and built as an experimental facility for plant cultivation systems, allowing the test of essential technologies and production procedures for future long-duration human space missions (Zabel et al., 2015). Detailed system analysis was conducted by the consortium partners resulting in a solid design (Bamsey et al., 2014, 2016; Zabel et al., 2016b), including a complete risk assessment (Santos et al., 2016). The MTF consists of two customized 20 foot high cube shipping containers, which are placed on top of a raised platform located $\sim 400 \mathrm{~m}$ south of Neumayer III. The research facility can be subdivided into three distinct sections:

- Airlock/ Cold-Porch (Blue section in Figure 2): A small room providing storage and a small air buffer to limit the entry of cold air when the main access door of the facility is used. This area is used for changing clothes. Furthermore, the main fresh water tank and the waste water tank are both located in the subfloor space of this section.

- Service Section (Red section in Figure 2): This section houses the primary control, atmosphere management, thermal control, power control and nutrient delivery systems of the MTF (Vrakking et al., 2017). Additionally, this section provides a working table including sink, trash bins, and storage for tools and consumables. In addition this section houses an independent rack-like plant cultivation system as part of the plant growth demonstrator for future deployment onboard the ISS (Boscheri et al., 2016, 2017).

- Future Exploration Greenhouse (FEG) (Green section in Figure 2): The main plant cultivation space of the MTF which includes multi-level plant growth racks operating in a controlled environment. The FEG is used to study plant cultivation and the related technologies for future planetary habitats (Zabel et al., 2017). 


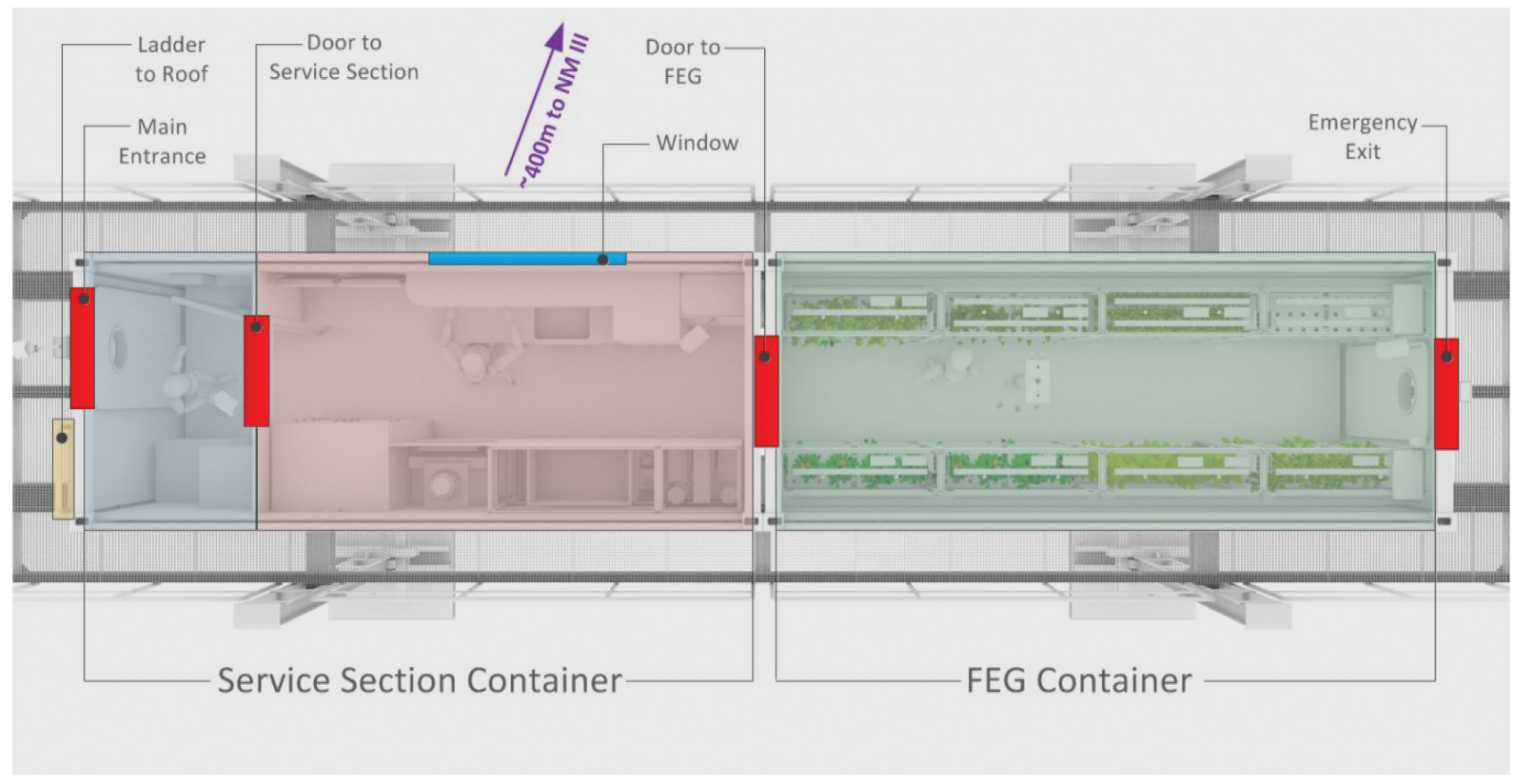

FIGURE 2 | Schematic top-view of the MTF. The blue section indicates the cold porch. The red area is called service section and houses a work desk and almost all greenhouse subsystems. The green section is the main plant cultivation space, called the FEG.

The technologies required to cultivate plants in a controlled environment are arranged in six different subsystems, which are briefly described in the following. Detailed information about the subsystems can be found in Zabel et al. (2017) and Vrakking et al. (2017).

1) The nutrient delivery subsystem adjusts the irrigation water's $\mathrm{pH}$ and EC value. Depending on the plant type (leafy or fruitbuilding crop), the mixing computer provides a dedicated nutrient solution that is delivered directly to the roots. Eight high-pressure pumps spray a fine nutrient mist inside the root compartment of each plant tray.

2) The atmosphere management subsystem regulates the temperature, humidity, and $\mathrm{CO}_{2}$ concentration within the FEG. Furthermore, the air flow is filtered (particle filter, HEPA, and activated carbon filter) and the humidity condensate water is recovered and fed back to the fresh water tank.

3) The thermal control subsystem is used to remove excess heat from the MTF and to provide a cool fluid for condensation of the humidity produced by the plants.

4) The illumination control subsystem consists of 42 fluidcooled LED fixtures integrated into the FEG. The light spectrum can freely be composed of red, blue, far-red, and white for each plant tray.

5) The power distribution subsystem provides electrical energy to all subsystems of the MTF. The electrical energy is generated in the Neumayer Station III and transmitted to the MTF.

6) The control and data handling subsystem consists of a set of independent programmable logic controllers which receive information from a wide range of sensors. Based on this information and defined program logics this subsystem controls all functions of the MTF. The control and data handling subsystem sends system telemetry to the mission control center in Bremen, Germany. Furthermore, every day a set of images taken from fixed positions inside the FEG is sent to the mission control center to allow remote experts observing plant development and to assist the on-site operator.

\section{Experiment Timeframe}

The MTF arrived in Antarctica on the 3rd of January 2018. The deployment took around 5 weeks and was finished in early February (Schubert et al., 2018). The winter-over on-site operator remained in Antarctica for the following 10 months until December 2018. In the following chapters "experimental phase" refers to the period from mid-February 2018 to midNovember 2018. The timeline of the experiment phase is shown in Figure 3.

The first plants were sown on February 7th 2018. The winterover period started with the departure of the last summer crew on February 18th. The first harvest of lettuce and leafy greens was on March 20th. The first cucumber harvest (29th of March) and first tomato harvest (16th of May) took place in the weeks that followed. The coldest temperature of the season was recorded in the morning of the 8 th of October 2018 with being $-43.5^{\circ} \mathrm{C}$. The winter-over period ended with the arrival of the first summer crew on November 2nd. The nominal operation phase of the MTF ended with the final harvest which took place on November 20th. The EDEN ISS winter-over operator departed a few days before Christmas 2018. 


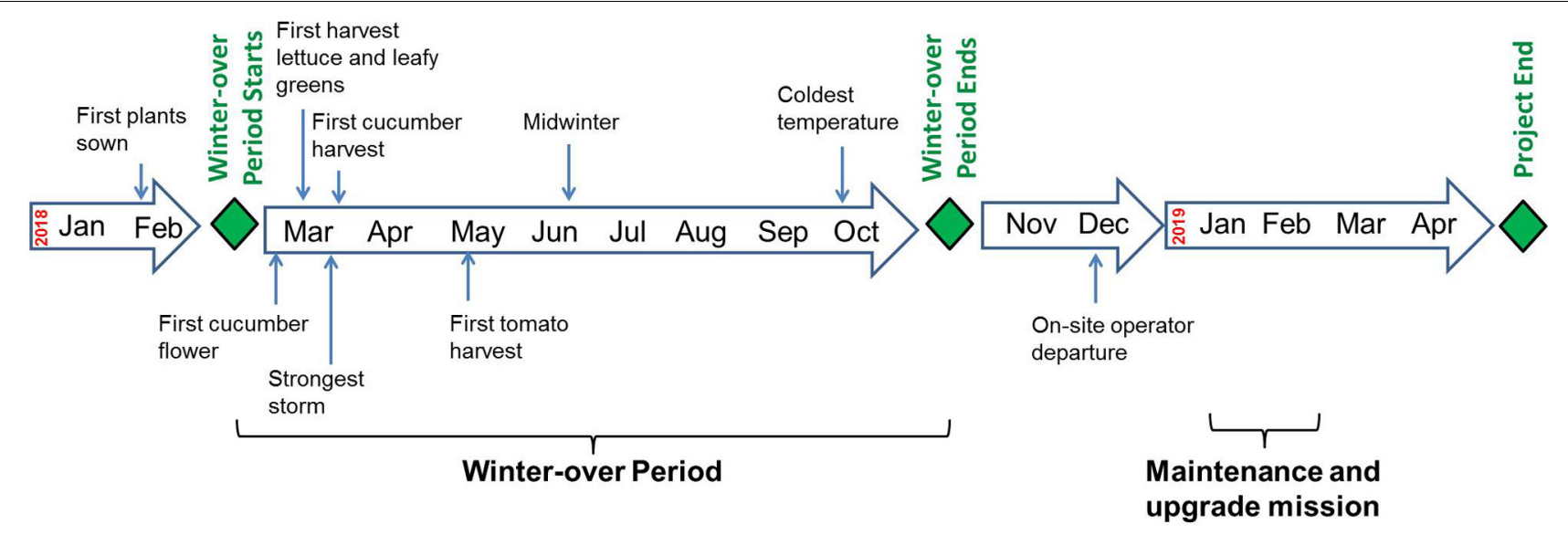

FIGURE 3 | Timeline of the EDEN ISS experiment phase (early 2018 to early 2019).

\section{Crop Species}

The EDEN ISS project team established a crop selection methodology in order to select crop species for the experiment campaign in Antarctica (Dueck et al., 2016). The focus of the project was on fresh pick-and-eat vegetables. Consequently, the list of cultivated crop species includes various varieties of lettuce and leafy greens accompanied by some fruit crops (e.g., tomato and cucumber).

The cultivated crops are organized in the five categories lettuce, leafy greens, herbs, fruit crops and tuber crops. The following crop varieties were cultivated:

- Lettuce: Batavia, Expertise, Outredgeous, Waldmann's Green

- Leafy greens: Two varieties of red mustard, swiss chard, arugula, mizuna

- Herbs: Basil, chives, parsley

- Fruit crops: Red dwarf tomato, orange dwarf tomato, cucumber (parthenocarpic, beit alpha)

- Tuber crops: Two varieties of radish, kohlrabi

- Miscellaneous crops: Two varieties of indeterminate tomato, two varieties of pepper, cilantro, mint, lemon balm, celery, strawberry.

Additional information (e.g., seed supplier) about the cultivated crop species can be found in Supplementary Material.

\section{Plant Treatment}

Most of the crop species were sown in rockwool blocks of $2 \times 2 \times$ $4 \mathrm{~cm}(\mathrm{~L} \times \mathrm{W} \times \mathrm{H})$, with the exception being parsley, chives and arugula. Those crops were sown directly in the cultivation trays on mats consisting of recycled cotton fibers. The crops grown in rockwool blocks were first put into a nursery tray for 1020 days depending on the species. Small amounts of nutrient solution were added manually to this tray in order to keep the rockwool blocks moist. Following the period in the nursery tray, the young plants were moved to the plant cultivation trays for maturation. Some crop species (cucumber, tomato, and pepper) required regular pruning of excess side shoots and leaves.
Two different methods for cultivation/harvest were used. Batch cultivation means that the whole plant was harvested when the plant reached a certain age. This technique was used for the lettuce varieties, radishes, and kohlrabi. Spread harvest means that only parts of the plant (leaves, fruits) were harvested allowing the plant to continue growing. All fruit crops, all herbs and all leafy greens were harvested this way.

Dates for sowing, transfer, pruning, and harvest events per cultivation tray were tracked continuously. Plant density can be determined from the type of cultivation tray which was used. Table 1 summarizes information regarding the plant treatment for each crop. Upon harvest fresh edible and inedible biomass was measured. The latter was measured separately for roots and stems/leaves. Sometimes plant material was dried using lyophilization in order to determine the dry biomass ratio which is the ratio of the dried biomass weight to the original fresh biomass weight. Drying plant material was limited due to the sizing of the equipment and due to the fact that dried material was required for each crop species.

Plant development was monitored by several cameras. From each plant cultivation tray, one photo from the top and one photo from the side were taken every day and send to a FTP server where all project partners could access the images. This way the horticulture scientists in the project team could advise the onsite operator on improvements for the cultivation of the crops. An image processing algorithm checked the photos automatically to detect issues with plant development. A multi-wavelength imaging system was setup in two positions to test whether this system can detect plant stress during growth (Zeidler et al., 2019).

\section{Environmental Conditions During Plant Cultivation Irrigation}

High pressure pumps in the FEG feed nutrient solution from the tanks to the plant cultivation trays via a hybrid aeroponic and nutrient film technique (Vrakking et al., 2017; Zabel et al., 2017). The solution was injected into the root zone via misting nozzles and the run-off served as a nutrient film once the roots had 
TABLE 1 | Summary of plant treatment information.

\begin{tabular}{|c|c|c|c|c|}
\hline $\begin{array}{l}\text { Crop } \\
\text { name }\end{array}$ & $\begin{array}{l}\text { Crop density } \\
\text { (plants/tray) }\end{array}$ & $\begin{array}{l}\text { Crop density } \\
\text { (plants } / \mathrm{m}^{2} \text { ) }\end{array}$ & Pruning & $\begin{array}{l}\text { Harvest } \\
\text { type }\end{array}$ \\
\hline Batavia & 6 & 18.3 & n.a. & Batch \\
\hline Expertise & 6 & 18.3 & n.a. & Batch \\
\hline Outredgeous & 6 & 18.3 & n.a. & Batch \\
\hline Waldmann's Green & 6 & 18.3 & n.a. & Batch \\
\hline Red Giant & 20 & 61.0 & n.a. & Spread \\
\hline Frizzy Lizzy & 20 & 61.0 & n.a. & Spread \\
\hline Swiss Chard & 12 & 36.6 & n.a. & Spread \\
\hline Arugula & 196 & 594.5 & n.a. & Batch \\
\hline Mizuna & 12 & 36.6 & n.a. & Spread \\
\hline Basil Dolly & 20 & 61.0 & Shortening of shoots when getting to close to LED lamps. & Spread \\
\hline Parsley & $\sim 100$ & 304.9 & n.a. & Spread \\
\hline Chives & $\sim 200$ & 609.8 & n.a. & Spread \\
\hline Tomato F1 3496B & 4 & 12.2 & $\begin{array}{l}\text { Periodic removal of withered leaves. Removal of withered } \\
\text { side shoots after harvest period to encourage plant to } \\
\text { regrow new side shoots. }\end{array}$ & Spread \\
\hline Tomato F1 1202 & 4 & 12.2 & $\begin{array}{l}\text { Periodic removal of withered leaves. Removal of withered } \\
\text { side shoots after harvest period to encourage plant to } \\
\text { regrow new side shoots. }\end{array}$ & Spread \\
\hline Cucumber Picowell & 2 & 6.1 & $\begin{array}{l}2 \text { shoots/stems per plant. Periodic removal of excess side } \\
\text { shoots and old leaves. }\end{array}$ & Spread \\
\hline Radish Raxe & 36 & 109.8 & n.a. & Batch \\
\hline Radish Lennox & 36 & 109.8 & n.a. & Batch \\
\hline Kohlrabi & $5-6$ & $15.2-18.3$ & $\begin{array}{l}\text { Removal of single leaves when those would block light } \\
\text { neighboring trays. }\end{array}$ & Batch \\
\hline
\end{tabular}

developed sufficiently. The irrigation schedule for the plants was a $30 \mathrm{~s}$ misting period every $6 \mathrm{~min}$. For the initial germination phase, the on-site operator manually supplied nutrient solution to the germination tray.

Two different nutrient solutions were provided to the crops, depending on their classification as either a leafy crop or a fruit crop. The two solutions were automatically mixed together in bulk solution tanks using deionized water and nutrients from concentrated stock solution bottles. The expected (initial) nutrient concentrations in the bulk solutions, based on the recipes developed for the project, can be seen in Table 2. The $\mathrm{pH}$ value of the solutions was managed by utilization of acid (1.25\% Nitric acid) and base (1\% Potassium hydroxide) stock solutions.

Based on the plant development observed throughout the operations phase, and in communication with remote experts in Europe, it was decided part way throughout the mission to adjust the composition for the fruit crop nutrient solution to include more calcium and to reduce the amount of potassium slightly. The concrete values are given in Table 2 .

There are only two main points of control for the Nutrient Delivery Subsystem (NDS), $\mathrm{pH}$ and EC. Both of these operated as expected throughout the first season of plant production. After the initial setup and testing of the growing systems in the beginning 30 days of operation, $\mathrm{pH}$ control was excellent. Any deviations from the set point were due to easily diagnosed technical issues (e.g., broken connectors on the acid delivery supply lines) and $\mathrm{pH}$ was never beyond a level suitable for plant growth. Tank 1 followed a higher control level
TABLE 2 | Nutrient concentration in 100 L bulk solution in NDS tanks during the experiment phase.

\begin{tabular}{lcc}
\hline $\begin{array}{l}\text { Nutrient } \\
\text { compound }\end{array}$ & $\begin{array}{c}\text { Leafy crop solution } \\
\text { concentrations }\end{array}$ & $\begin{array}{c}\text { Fruit crop solution } \\
\text { concentrations }\end{array}$ \\
\hline $\mathrm{NH} 4$ & $0.122 \mathrm{~mol}$ & $0.226 \mathrm{~mol}$ \\
$\mathrm{~K}$ & $1.028 \mathrm{~mol}$ & $1.503 \mathrm{~mol} / 1.378 \mathrm{~mol}$ \\
$\mathrm{Ca}$ & $0.419 \mathrm{~mol}$ & $0.597 \mathrm{~mol} / 0.711 \mathrm{~mol}$ \\
$\mathrm{Mg}$ & $0.135 \mathrm{~mol}$ & $0.226 \mathrm{~mol}$ \\
$\mathrm{NO} 3$ & $1.785 \mathrm{~mol}$ & $0.347 \mathrm{~mol} / 2.450 \mathrm{~mol}$ \\
$\mathrm{Cl}$ & $0.068 \mathrm{~mol}$ & $0.104 \mathrm{~mol}$ \\
$\mathrm{SO} 4$ & $0.109 \mathrm{~mol}$ & $0.267 \mathrm{~mol}$ \\
$\mathrm{P}$ & $0.189 \mathrm{~mol}$ & $5.161 \mathrm{mmol}$ \\
$\mathrm{Fe}$ & $3.795 \mathrm{mmol}$ & $2.059 \mathrm{mmol}$ \\
$\mathrm{Mn}$ & $0.189 \mathrm{mmol}$ & $0.825 \mathrm{mmol}$ \\
$\mathrm{Zn}$ & $0.244 \mathrm{mmol}$ & $4.321 \mathrm{mmol}$ \\
$\mathrm{B}$ & $2.840 \mathrm{mmol}$ & $0.164 \mathrm{mmol}$ \\
$\mathrm{Cu}$ & $0.068 \mathrm{mmol}$ & $0.103 \mathrm{mmol}$ \\
$\mathrm{Mo}$ & $0.041 \mathrm{mmol}$ & \\
\hline $\mathrm{NOtethat} \mathrm{the}$ & &
\end{tabular}

Note that the composition of the fruit crop solution was adapted during the mission. Adjusted values are shown in italic (The adjustment was necessary because a calcium deficit could be observed on the tomato plants, which most likely was the result of a bad K:Ca ratio).

than that of tank 2, and this was due to a programmed offset within the control software. Tank 1 averaged $\mathrm{pH} 6.06$ \pm 0.18 and tank 2 averaged $5.91 \pm 0.12$ over the entire growing period. 
EC monitoring results were similar to that of $\mathrm{pH}$. Control was excellent after the initial 30 day setup period. Each nutrient tank had a different EC set point, and control was tight with $2.21 \pm$ $0.13 \mathrm{mS} / \mathrm{cm}$ and $3.49 \pm 0.17 \mathrm{mS} / \mathrm{cm}$ in tanks 1 and 2 , respectively. At no time did EC deviate outside of a range amenable to plant growth and productivity.

Also monitored but not controlled was the nutrient solution temperature in the main nutrient tanks. Tank temperature followed that of the well-controlled room temperature and was quite stable with $19.90 \pm 0.74^{\circ} \mathrm{C}$ in tank 1 and $19.97 \pm$ $0.78^{\circ} \mathrm{C}$ in tank 2 .

As continuous determination of and control over individual ion concentrations was not possible, it was decided to periodically empty the bulk nutrient solution tanks and start with a new mixture. For tank 1 this procedure was done approximately once every 3 months, whereas for tank 2 the exchange was done about once every 2 months.

\section{Illumination}

A detailed description of the illumination subsystem is provided by Zabel et al. (2016b). Each plant cultivation tray has its own LED lamp which can be independently controlled in terms of light spectrum and light intensity. The LED lamps are of the model LX601 by the Swedish company Heliospectra which were modified with a liquid cooling system instead of the air cooling system. This way the light settings for each tray can be adjusted to the crop species and plant maturation stage. The photoperiod inside the FEG consisted of $15 \mathrm{~h}$ of full illumination per day and $1 \mathrm{~h}$ of reduced light intensity (50\% of nominal intensity) before and after the full illumination period. Consequently, the dark period was $7 \mathrm{~h}$ per day. The light spectrum mainly consisted of blue $(\sim 450 \mathrm{~nm})$ and red $(\sim 650 \mathrm{~nm})$ light and small portions of other wavelengths. The light intensity varied between 300 and 600 $\mu \mathrm{mol} /\left(\mathrm{m}^{2 *} \mathrm{~s}\right)$ at canopy level of a mature plant, depending on crop species and plant age. The following light intensities were measured for the different crops:

1. All four lettuce varieties: $330 \mu \mathrm{mol} /\left(\mathrm{m}^{2 *} \mathrm{~s}\right)$ at $16 \mathrm{~cm}$ height.

2. Red mustard, swiss chard, mizuna, basil, chives, parsley: 330 $\mu \mathrm{mol} /\left(\mathrm{m}^{2 *} \mathrm{~s}\right)$ at $16 \mathrm{~cm}$ height.

3. Radish, arugula: $600 \mu \mathrm{mol} /\left(\mathrm{m}^{2 *} \mathrm{~s}\right)$ at $16 \mathrm{~cm}$ height.

4. Tomato, Kohlrabi, pepper: $300-400 \mu \mathrm{mol} /\left(\mathrm{m}^{2 *} \mathrm{~s}\right)$ at $16 \mathrm{~cm}$ height.

5. Cucumber: $>500 \mu \mathrm{mol} /\left(\mathrm{m}^{2 *} \mathrm{~s}\right)$ at top of canopy.

\section{Atmosphere}

The temperature set points inside the FEG were $21^{\circ} \mathrm{C}$ during the photoperiod and $19^{\circ} \mathrm{C}$ during the dark period. Relative humidity was set to $65 \%$ and $\mathrm{CO}_{2}$ concentration to $1000 \mathrm{ppm}$. Figures 4-6 show the actual values measured within the FEG throughout the first year of operations. In general it can be seen that the temperature was maintained at the set points, fluctuating between 21 degrees during the photoperiod and 19 degrees during the dark period.

During the Antarctic winter season, at very low external temperatures, the facility failed to maintain temperature during the dark period, resulting in temperature drops down to $16^{\circ} \mathrm{C}$. Some off-nominal events with the thermal control subsystem resulted in temperature increases beyond the $21^{\circ} \mathrm{C}$ set point. Furthermore, a number of measurements are erroneous (showing $0^{\circ} \mathrm{C}$ ) due to communication issues in the command and data handling subsystem.

The relative humidity within the FEG showed larger deviations from the set point of 65\%, in particular between April and July the relative humidity would go as high as $86 \%$ for periods of a few hours. This was the result of issues with the condensate recovery design, which had to be mitigated by adjusting flow rates and coolant temperatures within the thermal control subsystem and fine-tuning the control logic. Following the troubleshooting phase, and implementing countermeasures, the relative humidity control throughout the later phase of the experiment phase was significantly improved.

The $\mathrm{CO}_{2}$ concentration within the FEG was almost always higher than the set point of $1000 \mathrm{ppm}$, due to the fact that the on-site operator frequently (almost every day) worked within the greenhouse, emitting $\mathrm{CO}_{2}$, and there is no $\mathrm{CO}_{2}$ removal system implemented within the facility. Depending on the time (e.g., 1$4 \mathrm{~h}$ ) spent inside the FEG, the $\mathrm{CO}_{2}$ concentration went up to $\sim 2000$ ppm or even $\sim 4000$ ppm. Normally the plants in the FEG would need around 1 day to consume enough $\mathrm{CO}_{2}$ to bring the concentration back down to the set point of $1000 \mathrm{ppm}$.

A desired maximum ethylene concentration of $15 \mathrm{ppb}$ was defined for the greenhouse, with up to $100 \mathrm{ppb}$ allowed for durations of no more than $30 \mathrm{~min}$. An activated carbon filter was implemented into the atmosphere management subsystem to remove ethylene. However, no sensor was installed to provide measurements of the actual concentration within the facility.

\section{RESULTS}

\section{Overview}

The FEG produced a total of around $268 \mathrm{~kg}$ of fresh edible biomass. Most of this food was consumed by the 10 person strong winter-over crew. Small amounts were set aside to perform a wide range of measurements (e.g., dry weight ratio, nitrate content). The fruit crops produced by far the most food $(105.4 \mathrm{~kg})$ followed by the lettuce $(56.4 \mathrm{~kg})$, leafy greens $(49.1 \mathrm{~kg})$, tuber crops $(26.8 \mathrm{~kg})$, herbs $(12.2 \mathrm{~kg})$, and miscellaneous crops $(18.4 \mathrm{~kg})$.

The evaluation of the inedible biomass was rather complicated, because some of the inedible biomass was harvested wet (e.g., roots and rock wool), some fresh (e.g., radish leaves), and some dry (e.g., withered tomato leaves). Combining all three values into a single figure for all crops was challenging, because the dry biomass ratio was required. In total roughly $11.2 \mathrm{~kg}$ of dry inedible biomass (excluding misc. crops) was harvested.

The following chapters give a detailed overview of the biomass production of each crop species.

\section{Lettuce}

In total 18 cycles of lettuce cultivation were performed in the experiment phase. Between 11 and 15, depending on the lettuce cultivars, of these cycles are valid for evaluation. The 


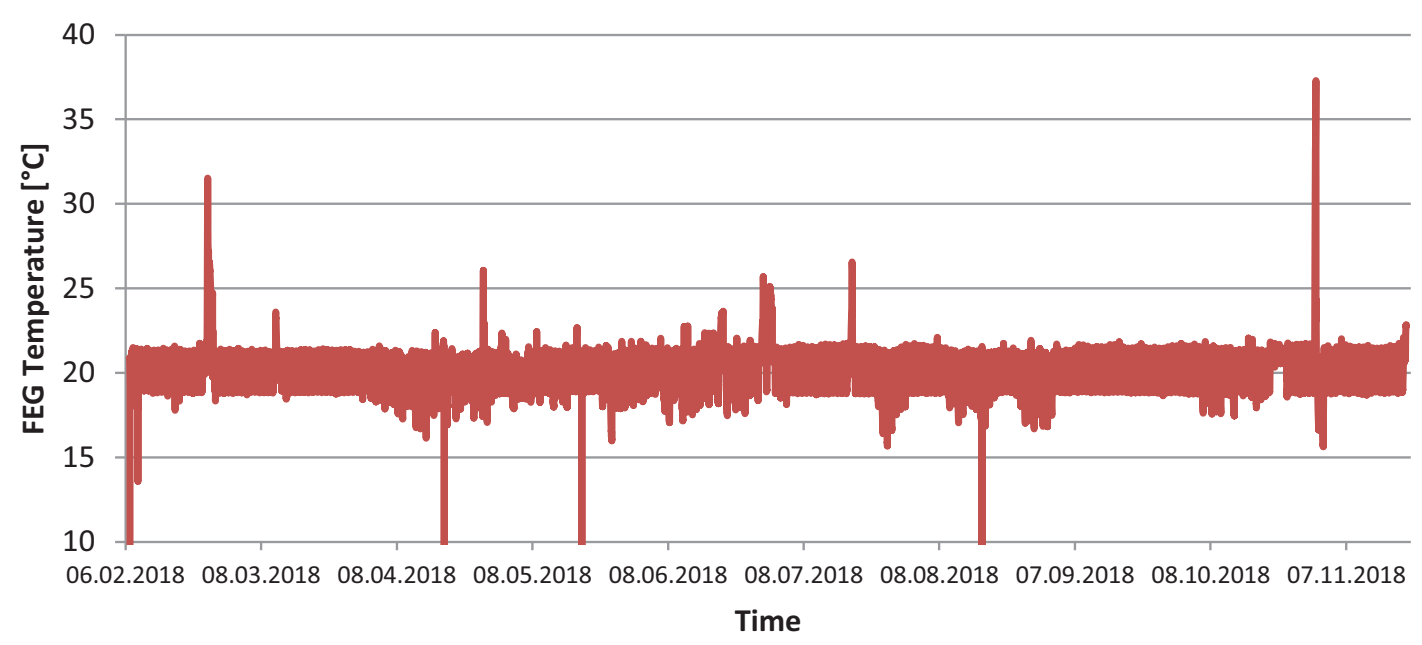

FIGURE 4 | FEG air temperature during the experimental phase (one data point per minute).

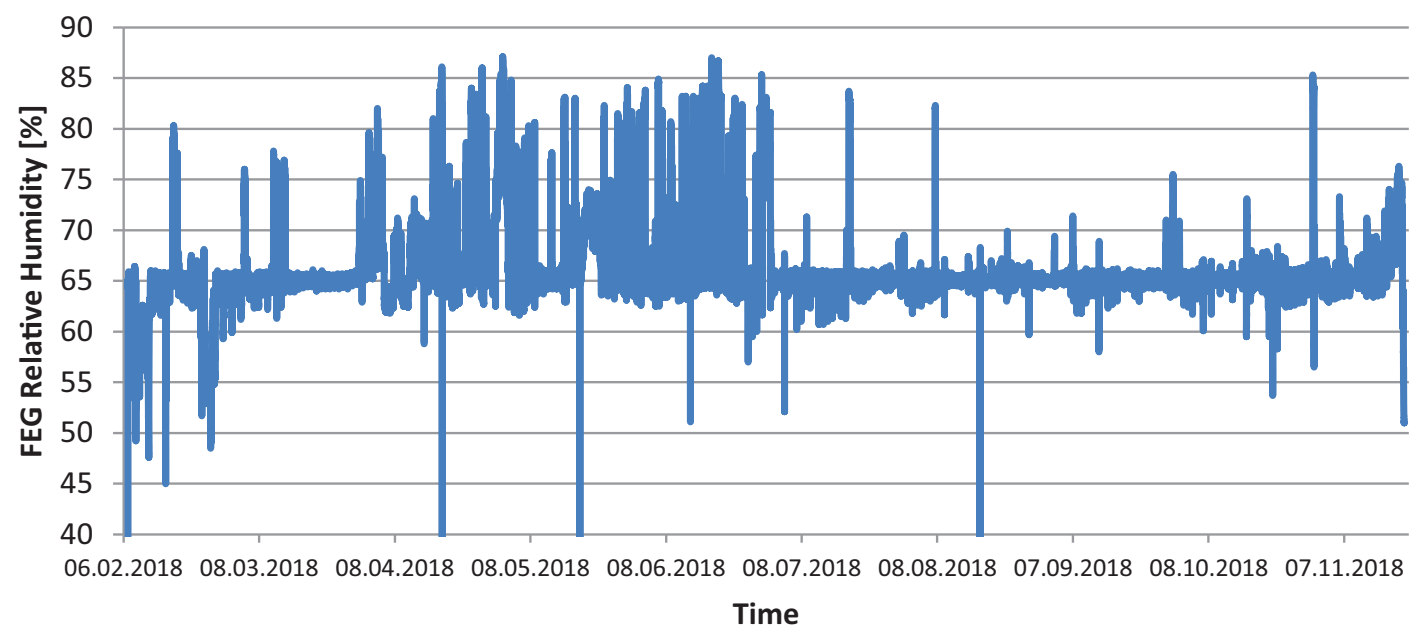

FIGURE 5 | FEG relative humidity during the experimental phase (one data point per minute).

remaining cycles have been excluded from evaluation due to various reasons (e.g., extensive sampling of plant material). The four lettuce varieties were always sown and harvested at the same time and cultivated in trays located in the same rack and with the same environmental conditions. Nevertheless, the biomass production varied greatly among the crop varieties, as can be seen in Table 3. Waldmann's Green clearly produced the most biomass per tray, followed by Expertise, Outredgeous, and Batavia. Data on the dry weight ratio for edible and inedible biomass can be found in Table 4 and dry inedible biomass production in Table 5.

For all lettuce varieties a large variance between batches could be observed and this is also visible in the values of the standard error. There was a decline in biomass harvest roughly in the mid of the season. The productivity of the batches harvested in June and July was less than half of the maximum value.

\section{Leafy Greens}

Five different leafy greens were cultivated. Arugula was harvested in batches, while the other leafy greens (red mustard, swiss chard, and mizuna) were spread harvested. Furthermore, arugula was cultivated with two different light settings. Table 6 shows the biomass production values of all leafy greens. Mizuna and arugula (high light intensity, $600 \mu \mathrm{mol} /\left(\mathrm{m}^{2 *} \mathrm{~s}\right)$ at $16 \mathrm{~cm}$ height) performed best followed by Swiss chard, both red mustard varieties and arugula (low light intensity, $330 \mu \mathrm{mol} /\left(\mathrm{m}^{2 *} \mathrm{~s}\right)$ at $16 \mathrm{~cm}$ height) which all had a similar output. Due to the batch harvesting of arugula and the availability of two trays for simultaneous cultivation 17 cycles are available for evaluation. For the other leafy greens, only between 1 and 3 cycles, depending on the cultivar, of data are available. Data on the dry weight ratio for edible and inedible biomass can be found in Table $\mathbf{4}$ and dry inedible biomass production in Table 5 . 


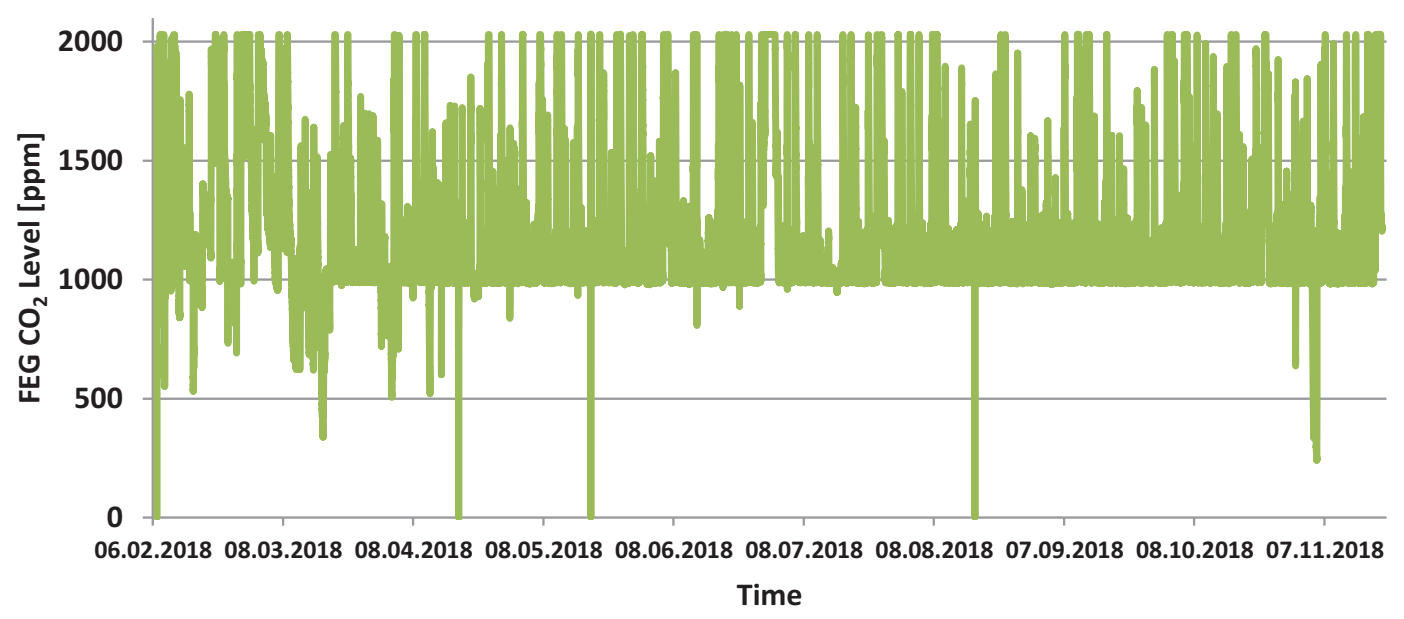

FIGURE 6 | FEG atmospheric $\mathrm{CO}_{2}$ level during the experiment phase (one data point per minute). Note that the sensor used had an upper limit of 2000 ppm. This value was exceeded frequently due to the presence of the on-site operator.

TABLE 3 | Lettuce edible fresh weight production values.

\begin{tabular}{|c|c|c|c|c|c|}
\hline Crop name & $\begin{array}{l}\text { Cycles for } \\
\text { evaluation }\end{array}$ & $\begin{array}{c}\text { Average } \\
\text { cultivation } \\
\text { cycle length (d) }\end{array}$ & $\begin{array}{c}\text { Edible fresh } \\
\text { weight per } \\
\text { cultivation area } \\
\quad\left(\mathrm{kg} / \mathrm{m}^{2}\right)\end{array}$ & $\begin{array}{c}\text { Time normalized } \\
\text { edible fresh weight } \\
\text { per cultivation area } \\
\left(\mathrm{kg} / \mathrm{m}^{2} / \mathrm{d}\right)\end{array}$ & $\begin{array}{c}\text { Edible fresh } \\
\text { weight per } \\
\text { cultivation volume } \\
\left(\mathrm{kg} / \mathrm{m}^{3}\right)\end{array}$ \\
\hline Batavia & 15 & 38.0 & $1.56 \pm 0.12(0.98-2.46)$ & $0.043 \pm 0.002(0.028-0.059)$ & $1.77-4.43$ \\
\hline Expertise & 15 & 38.0 & $2.38 \pm 0.16(1.50-3.50)$ & $0.065 \pm 0.003(0.043-0.084)$ & $2.70-6.31$ \\
\hline Outredgeous & 14 & 37.9 & $2.10 \pm 0.15(1.39-2.65)$ & $0.058 \pm 0.003(0.038-0.072)$ & $2.50-4.77$ \\
\hline
\end{tabular}

Mean \pm standard error is given.

\section{Herbs}

Basil, chives, and parsley were cultivated during the experiment phase. All herbs were spread harvested. Parsley and chives were grown for almost the complete duration of the experiment phase (266 out of 286 days). Basil had to be removed from the trays and sown anew regularly, because the plants grew rapidly, reaching up to the LED lamps after several weeks. Four cycles of basil were grown of which two are suitable for data evaluation. The other two had to be excluded because the first cycle used an inappropriate growing procedure and the last cycle was too short. The three herbs have a similar production rate of edible biomass with parsley and basil being slightly ahead of chives. The biomass production data for the herbs can be found in Table 7. Data on the dry weight ratio for edible and inedible biomass can be found in Table 4 and dry inedible biomass production in Table 5.

\section{Fruit Crops}

Fruit crops produced the most edible biomass during the experiment phase. Especially the cucumber showed an exceptional productivity of more than $100 \mathrm{~g} /\left(\right.$ tray $\left.^{*} \mathrm{~d}\right)$ and consequently contributed the most edible biomass of all cultivated crop species. The two dwarf tomato varieties show a similar productivity, with the orange tomato being slightly lower than the red one. The tomato plants were grown in a single cycle lasting the full experimental phase, while the cucumber plants were grown in two cycles. The biomass production data for the fruit crops can be found in Table 8. Data on the dry weight ratio for edible and inedible biomass can be found in Table 4 and dry inedible biomass production in Table 5.

\section{Tuber Crops}

Tuber crops (radish and kohlrabi) were harvested in batches. 20 batches of radishes were grown during the experiment phase, 10 of each variety. Of those 20 batches, 19 were suitable for evaluation. One batch had to be excluded from evaluation due to extensive sampling of plant material for microbial and matter analyses (e.g., nitrate content, antioxidants). Furthermore, seven batches of kohlrabi were grown. Kohlrabi produced more biomass per cultivation area and time normalized than radish. The biomass production data for the fruit crops can be found in Table 9. Data on the dry weight ratio for edible and inedible biomass can be found in Table 4 and dry inedible biomass production in Table 5.

\section{DISCUSSION}

During the 286-day operational phase in 2018 the EDEN ISS MTF produced $268 \mathrm{~kg}$ of fresh edible biomass, which is a 
TABLE 4 | Dry weight (DW) ratio values for edible and inedible biomass.

\begin{tabular}{|c|c|c|c|}
\hline $\begin{array}{l}\text { Crop } \\
\text { name }\end{array}$ & $\begin{array}{c}\text { Edible } \\
\text { biomass } \\
\text { DW ratio } \\
\text { (\%) }\end{array}$ & $\begin{array}{c}\text { Inedible } \\
\text { biomass DW } \\
\text { ratio (roots) } \\
(\%)\end{array}$ & $\begin{array}{c}\text { Inedible } \\
\text { biomass DW } \\
\text { ratio (stems/leaves) } \\
(\%)\end{array}$ \\
\hline Batavia & $\begin{array}{c}5.79 \pm 0.30 \\
N=12\end{array}$ & $\begin{array}{c}3.90 \pm 1.26 \\
N=3\end{array}$ & n.a. \\
\hline Expertise & $\begin{array}{c}6.09 \pm 0.34 \\
N=12\end{array}$ & $\begin{array}{c}4.57 \pm 1.18 \\
N=3\end{array}$ & n.a. \\
\hline Outredgeous & $\begin{array}{c}6.61 \pm 0.35 \\
N=12\end{array}$ & $\begin{array}{c}4.82 \pm 0.92 \\
N=3\end{array}$ & n.a. \\
\hline Waldmann's Green & $\begin{array}{c}6.35 \pm 0.44 \\
N=12\end{array}$ & $\begin{array}{c}2.69 \pm 0.29 \\
N=3\end{array}$ & n.a. \\
\hline Red Giant & $\begin{array}{c}6.09 \pm 0.13 \\
N=17\end{array}$ & $\begin{array}{c}4.07 \\
N=1\end{array}$ & $\begin{array}{l}6.43 \\
N=1\end{array}$ \\
\hline Frizzy Lizzy & $\begin{array}{c}6.04 \pm 0.13 \\
N=17\end{array}$ & $\begin{array}{l}4.07 \\
N=1\end{array}$ & $\begin{array}{l}5.53 \\
N=1\end{array}$ \\
\hline Swiss Chard & $\begin{array}{c}7.16 \pm 0.12 \\
N=10\end{array}$ & $\begin{array}{c}10.08 \pm 3.09 \\
N=3\end{array}$ & $\begin{array}{c}6.26 \pm 1.74 \\
N=4\end{array}$ \\
\hline Arugula & $\begin{array}{c}6.52 \pm 0.40 \\
N=16\end{array}$ & $\begin{array}{c}4.24 \pm 0.21 \\
N=6\end{array}$ & n.a. \\
\hline Mizuna & $\begin{array}{c}6.37 \pm 0.49 \\
N=3\end{array}$ & Not measured & Not measured \\
\hline Basil Dolly & $\begin{array}{c}8.64 \pm 0.31 \\
N=19\end{array}$ & $\begin{array}{c}3.18 \pm 1.03 \\
N=2\end{array}$ & $\begin{array}{c}6.02 \pm 2.48 \\
N=2\end{array}$ \\
\hline Parsley & $\begin{array}{c}10.93 \pm 0.09 \\
N=10\end{array}$ & $\begin{array}{l}7.15 \\
N=1\end{array}$ & Not measured \\
\hline Chives & $\begin{array}{c}8.84 \pm 0.10 \\
N=10\end{array}$ & $\begin{array}{l}7.15 \\
N=1\end{array}$ & Not measured \\
\hline Tomato F1 3496B & $\begin{array}{c}12.66 \pm 0.29 \\
N=13\end{array}$ & $\begin{array}{c}10.21 \pm 1.16 \\
N=4\end{array}$ & $\begin{array}{c}25.43 \pm 1.15 \\
N=10\end{array}$ \\
\hline Tomato F1 1202 & $\begin{array}{c}13.36 \pm 0.75 \\
N=13\end{array}$ & $\begin{array}{c}9.63 \pm 1.04 \\
N=4\end{array}$ & $\begin{array}{c}28.35 \pm 3.94 \\
N=10\end{array}$ \\
\hline Cucumber Picowell & $\begin{array}{c}4.43 \pm 0.13 \\
N=18\end{array}$ & $\begin{array}{c}3.20 \pm 0.39 \\
N=4\end{array}$ & $\begin{array}{c}16.51 \pm 0.88 \\
N=11\end{array}$ \\
\hline Radish Raxe & $\begin{array}{c}5.79 \pm 0.17 \\
N=15\end{array}$ & $\begin{array}{c}0.59 \pm 0.06 \\
N=3\end{array}$ & $\begin{array}{c}8.09 \pm 0.35 \\
N=18\end{array}$ \\
\hline Radish Lennox & Not measured & Not measured & Not measured \\
\hline Kohlrabi & $\begin{array}{c}7.17 \pm 0.35 \\
N=5\end{array}$ & $\begin{array}{c}3.78 \pm 0.51 \\
N=4\end{array}$ & $\begin{array}{c}\text { Leaves: } \\
9.49 \pm 0.26 \\
N=8 \\
\text { Skin: } \\
7.97 \pm 0.28 \\
N=6\end{array}$ \\
\hline
\end{tabular}

Mean \pm standard error is given.

good result for the first year of operation. The production rate was $21.44 \mathrm{~kg} / \mathrm{m}^{2}$. This results in a time normalized production rate of $0.075 \mathrm{~kg} /\left(\mathrm{m}^{2 *} \mathrm{~d}\right)$. The pepper plants did only produce small amounts of fruit in the 2018 EDEN ISS season, but took up $11 \%$ of the cultivation area. When correcting the overall production of EDEN ISS by removing the pepper plants from the calculation the edible fresh biomass production rate increases to $0.089 \mathrm{~kg} /\left(\mathrm{m}^{2 *} \mathrm{~d}\right)$. The South Pole Food Growth Chamber (SPFGC), an indoor plant cultivation room at the
TABLE 5 | Inedible biomass production overview.

\begin{tabular}{|c|c|c|}
\hline $\begin{array}{l}\text { Crop } \\
\text { name }\end{array}$ & $\begin{array}{l}\text { Roots } \\
\text { DW }\end{array}$ & $\begin{array}{l}\text { Stems and } \\
\text { leaves DW }\end{array}$ \\
\hline Batavia & $8.9-34.2 \mathrm{~g} / \mathrm{m}^{2}(\mathrm{~N}=3)$ & n.a. \\
\hline Expertise & $20.5-37.9 \mathrm{~g} / \mathrm{m}^{2}(\mathrm{~N}=3)$ & n.a. \\
\hline Outredgeous & $21.1-38.5 \mathrm{~g} / \mathrm{m}^{2}(\mathrm{~N}=3)$ & n.a. \\
\hline Waldmann's Green & $11.3-22.9 \mathrm{~g} / \mathrm{m}^{2}(\mathrm{~N}=3)$ & n.a. \\
\hline Red Giant & $42.0 \mathrm{~g} / \mathrm{m}^{2}(N=1)$ & $75.6 \mathrm{~g} / \mathrm{m}^{2}(N=1)$ \\
\hline Frizzy Lizzy & $42.0 \mathrm{~g} / \mathrm{m}^{2}(N=1)$ & $20.8 \mathrm{~g} / \mathrm{m}^{2}(N=1)$ \\
\hline Swiss Chard & $21.8-47.0 \mathrm{~g} / \mathrm{m}^{2}(\mathrm{~N}=2)$ & $81.4-94.4 \mathrm{~g} / \mathrm{m}^{2}(N=2)$ \\
\hline $\begin{array}{l}\text { Arugula (initial light } \\
\text { intensity) }\end{array}$ & Not measured & n.a. \\
\hline $\begin{array}{l}\text { Arugula (higher light } \\
\text { intensity) }\end{array}$ & $21.3-58.8 \mathrm{~g} / \mathrm{m}^{2}(N=6)$ & n.a. \\
\hline Mizuna & Not measured & Not measured \\
\hline Basil Dolly & $76.5-127.1 \mathrm{~g} / \mathrm{m}^{2}(N=2)$ & $179.3-252.1 \mathrm{~g} / \mathrm{m}^{2}(N=2)$ \\
\hline Parsley & $146.3 \mathrm{~g} / \mathrm{m}^{2}(\mathrm{~N}=1)$ & $113.4 \mathrm{~g} / \mathrm{m}^{2}(N=1)$ \\
\hline Chives & $146.3 \mathrm{~g} / \mathrm{m}^{2}(N=1)$ & $1033.5 \mathrm{~g} / \mathrm{m}^{2}(N=1)$ \\
\hline Tomato F1 3496B & $1411-1713 \mathrm{~g} / \mathrm{m}^{2}(\mathrm{~N}=2)$ & Erroneous measurement \\
\hline Tomato F1 1202 & $1153-1567 \mathrm{~g} / \mathrm{m}^{2}(\mathrm{~N}=2)$ & Erroneous measurement \\
\hline Cucumber Picowell & $93.8-133.5 \mathrm{~g} / \mathrm{m}^{2}(N=4)$ & Erroneous measurement \\
\hline Radish Raxe & $96.4-99.4 \mathrm{~g} / \mathrm{m}^{2}(\mathrm{~N}=3)$ & $89.0-123.5 \mathrm{~g} / \mathrm{m}^{2}(\mathrm{~N}=2)$ \\
\hline Radish Lennox & Not measured & Not measured \\
\hline Kohlrabi & $27.8-51.0 \mathrm{~g} / \mathrm{m}^{2}(\mathrm{~N}=3)$ & $198.4-253.3 \mathrm{~g} / \mathrm{m}^{2}(N=2)$ \\
\hline
\end{tabular}

American South Pole Station (Patterson et al., 2008), had a production rate of $0.130 \mathrm{~kg} /\left(\mathrm{m}^{2 *} \mathrm{~d}\right.$ ) in 2006 (Patterson et al., 2012). The SPGFC mainly produced lettuce (32\% of total fresh edible biomass) and cucumber (41\%) and only small amounts of herbs $(6 \%)$, tomato $(4 \%)$, and other crops $(17 \%)$. Whereas the distribution in EDEN ISS in 2018 was $21 \%$ lettuce, $18 \%$ leafy greens, $25 \%$ cucumber, $5 \%$ herbs, $14 \%$ tomato, $10 \%$ tuber vegetables and $7 \%$ other crops. Since cucumber have the highest production rate per unit area and time, the higher ratio of cucumber in the SPFGC harvest can explain the better overall production rate of fresh edible biomass compared to EDEN ISS to some degree.

Plant cultivation experiments have been conducted by an EDEN ISS project partner in advance of the Antarctic experimental campaign (Meinen et al., 2018). When comparing the results from Antarctica with the experiments conducted in plant growth chambers in Europe, the yield per unit time and cultivation area of lettuce was higher in Antarctica than in the experiments in Europe. The yield of the red mustard frizzy lizzy, Swiss chard, parsley and chives was better in the plant growth chambers in Europe than in Antarctica, but the plant density in those experiments was much higher.

The yield of lettuce was better than (Richards et al., 2004b; Edney et al., 2006) or equal to (Richards et al., 2004a) some other experiments, but only half as good as the values achieved by the BPC (Wheeler et al., 2008). No reliable reference data could be found for the leafy greens mizuna and the red mustard red giant. This is also the issue with the cultivated herbs basil, parsley and chives for which the only comparison that could be made was 
TABLE 6 | Leafy greens edible fresh weight production values.

\begin{tabular}{|c|c|c|c|c|c|}
\hline Crop name & $\begin{array}{l}\text { Cycles for } \\
\text { evaluation }\end{array}$ & $\begin{array}{c}\text { Average } \\
\text { cultivation } \\
\text { cycle length (d) }\end{array}$ & $\begin{array}{c}\text { Edible fresh } \\
\text { weight per } \\
\text { cultivation area } \\
\qquad\left(\mathrm{kg} / \mathrm{m}^{2}\right)\end{array}$ & $\begin{array}{c}\text { Time normalized } \\
\text { edible fresh weight } \\
\text { per cultivation area } \\
\qquad\left(\mathrm{kg} / \mathrm{m}^{2} / \mathrm{d}\right)\end{array}$ & $\begin{array}{c}\text { Edible fresh } \\
\text { weight per cultivation } \\
\text { volume } \\
\left(\mathbf{k g} / \mathrm{m}^{3}\right)\end{array}$ \\
\hline $\begin{array}{l}\text { Arugula (initial light intensity, } \\
330 \mu \mathrm{mol} /\left(\mathrm{m}^{2 *} \mathrm{~s}\right) \text { at } 16 \mathrm{~cm} \\
\text { height) }\end{array}$ & 9 & 24.2 & $3.05 \pm 0.27(1.87-4.34)$ & $0.111 \pm 0.007(0.078-0.140)$ & $3.37-7.82$ \\
\hline $\begin{array}{l}\text { Arugula (higher light } \\
\text { intensity, } 600 \mu \mathrm{mol} /\left(\mathrm{m}^{2 \star} \mathrm{s}\right) \\
\text { at } 16 \mathrm{~cm} \text { height) }\end{array}$ & 8 & 29.0 & $5.49 \pm 0.40(4.13-6.90)$ & $0.188 \pm 0.011(0.153-0.222)$ & $7.44-12.43$ \\
\hline Swiss Chard & 3 & 90.0 & $9.26 \pm 1.13(7.35-11.28)$ & $0.102 \pm 0.010(0.088-0.121)$ & $13.24-20.32$ \\
\hline Red Giant & 3 & 82.7 & $10.78 \pm 0.52(8.73-11.96)$ & $0.130 \pm 0.004(0.106-0.145)$ & $15.72-21.54$ \\
\hline Frizzy Lizzy & 3 & 82.7 & $8.93 \pm 0.48(7.11-10.37)$ & $0.107 \pm 0.005(0.086-0.125)$ & $12.80-18.70$ \\
\hline Mizuna & 1 & 119.0 & 23.11 & 0.194 & 41.64 \\
\hline
\end{tabular}

Mean \pm standard error is given.

TABLE 7 | Herbs edible fresh weight production values.

\begin{tabular}{|c|c|c|c|c|c|}
\hline Crop name & $\begin{array}{l}\text { Cycles for } \\
\text { evaluation }\end{array}$ & $\begin{array}{l}\text { Average } \\
\text { cultivation } \\
\text { cycle } \\
\text { length (d) }\end{array}$ & $\begin{array}{l}\text { Edible fresh } \\
\text { weight per } \\
\text { cultivation } \\
\text { area }\left(\mathrm{kg} / \mathrm{m}^{2}\right)\end{array}$ & $\begin{array}{l}\text { Time normalized } \\
\text { edible fresh weight } \\
\text { per cultivation } \\
\text { area }\left(\mathbf{k g} / \mathrm{m}^{2} / \mathrm{d}\right)\end{array}$ & $\begin{array}{c}\text { Edible fresh } \\
\text { weight per } \\
\text { cultivation } \\
\text { volume }\left(\mathrm{kg} / \mathrm{m}^{3}\right)\end{array}$ \\
\hline Basil & 2 & 121.0 & $7.30 \pm 0.93(6.37-8.22)$ & $0.060 \pm 0.008(0.052-0.069)$ & $11.48-14.81$ \\
\hline Chives & 1 & 266.0 & 13.97 & 0.053 & 25.17 \\
\hline Parsley & 1 & 266.0 & 16.46 & 0.062 & 29.66 \\
\hline
\end{tabular}

Mean \pm standard error is given.

TABLE 8 | Fruit crops edible fresh weight production values.

\begin{tabular}{|c|c|c|c|c|c|c|}
\hline Crop name & $\begin{array}{l}\text { Cycles for } \\
\text { evaluation }\end{array}$ & $\begin{array}{l}\text { Average } \\
\text { cultivation } \\
\text { cycle } \\
\text { length (d) }\end{array}$ & $\begin{array}{l}\text { Average } \\
\text { fruit per } \\
\text { cycle per } \\
\text { tray }\end{array}$ & $\begin{array}{l}\text { Edible fresh } \\
\text { weight per } \\
\text { cultivation } \\
\text { area }\left(\mathrm{kg} / \mathrm{m}^{2}\right)\end{array}$ & $\begin{array}{l}\text { Time normalized } \\
\text { edible fresh weight } \\
\text { per cultivation } \\
\text { area }\left(\mathrm{kg} / \mathrm{m}^{2} / \mathrm{d}\right)\end{array}$ & $\begin{array}{c}\text { Edible fresh } \\
\text { weight per } \\
\text { cultivation } \\
\text { volume }\left(\mathrm{kg} / \mathrm{m}^{3}\right)\end{array}$ \\
\hline Tomato F1 3689B & 2 & 286.0 & 994 & $13.06 \pm 0.00(13.06-13.07)$ & $0.046 \pm 0.000(0.046-0.046)$ & $11.82-11.83$ \\
\hline Tomato F1 1202 & 2 & 286.0 & 1372 & $14.90 \pm 1.84(13.06-16.78)$ & $0.052 \pm 0.006(0.046-0.059)$ & $11.82-15.19$ \\
\hline Cucumber Picowell & 4 & 161.0 & 208 & $50.88 \pm 4.38(41.70-59.98)$ & $0.321 \pm 0.041(0.241-0.403)$ & $18.45-26.54$ \\
\hline
\end{tabular}

Mean \pm standard error is given.

TABLE 9 | Tuber crops edible fresh weight production values.

\begin{tabular}{|c|c|c|c|c|c|}
\hline Crop name & $\begin{array}{l}\text { Cycles for } \\
\text { evaluation }\end{array}$ & $\begin{array}{l}\text { Average } \\
\text { cultivation } \\
\text { cycle } \\
\text { length (d) }\end{array}$ & $\begin{array}{l}\text { Edible fresh } \\
\text { weight per } \\
\text { cultivation } \\
\text { area }\left(\mathrm{kg} / \mathrm{m}^{2}\right)\end{array}$ & $\begin{array}{l}\text { Time normalized } \\
\text { edible fresh weight } \\
\text { per cultivation } \\
\text { area }\left(\mathrm{kg} / \mathrm{m}^{2} / \mathrm{d}\right)\end{array}$ & $\begin{array}{l}\text { Edible fresh } \\
\text { weight per } \\
\text { cultivation } \\
\text { volume }\left(\mathrm{kg} / \mathrm{m}^{3}\right)\end{array}$ \\
\hline Radish Raxe & 10 & 22.6 & $1.82 \pm 0.24(1.10-3.21)$ & $0.078 \pm 0.009(0.044-0.119)$ & $1.98-5.78$ \\
\hline Radish Lennox & 9 & 23.0 & $1.33 \pm 0.06(1.07-1.68)$ & $0.059 \pm 0.002(0.045-0.068)$ & $1.93-3.03$ \\
\hline Kohlrabi & 6 & 58.71 & $8.11 \pm 0.81$ (5.74-10.58) & $0.141 \pm 0.008(0.113-0.165)$ & $10.34-19.06$ \\
\hline
\end{tabular}

Mean \pm standard error is given.

with the preparatory experiments of the project (Meinen et al., 2018). The dwarf tomato yield was basically equal to experiments with similar cultivars (Spencer et al., 2019; Wang et al., 2019), but smaller compared to the BPC results (Wheeler et al., 2008) which were most likely done with normal sized tomato crops. The yield of the EDEN ISS cucumber cultivation was better compared to the experiments with this crop in Lunar Palace 1 (Fu et al., 2016). The comparisons between the results from the 
TABLE 10 | Comparison of EDEN ISS time normalized edible fresh biomass production rate to the results of experiments by other scientists.

\begin{tabular}{|c|c|c|}
\hline Crop name & EDEN ISS $\left[\mathrm{kg} /\left(\mathrm{m}^{2 *} \mathrm{~d}\right)\right]$ & Experiments by other scientists $\left[\mathrm{kg} /\left(\mathrm{m}^{2 \star} \mathrm{d}\right)\right]$ \\
\hline Batavia & 0.043 & Meinen et al. (2018): 0.033; same environmental conditions. \\
\hline Expertise & 0.065 & Meinen et al. (2018): 0.051; same environmental conditions. \\
\hline Outredgeous & 0.058 & $\begin{array}{l}\text { Meinen et al. (2018): 0.040; same environmental conditions. Richards et al. (2004b): } 0.036^{2} ; 25^{\circ} \mathrm{C} \text {, } \\
65 \% \mathrm{rh}, 1200 \mathrm{ppm} \mathrm{CO}_{2}, 300 \mu \mathrm{mol} /\left(\mathrm{m}^{2 \star} \mathrm{s}\right), 16 \mathrm{~h} \text { photoperiod. }\end{array}$ \\
\hline Waldmann's Green & 0.080 & $\begin{array}{l}\text { Wheeler et al. (2008): } 0.161^{2} ; 23^{\circ} \mathrm{C}, 65-75 \% \mathrm{rh}, 1000-1200 \mathrm{ppm} \mathrm{CO} 2,280-336 \mu \mathrm{mol} /\left(\mathrm{m}^{2 \star} \mathrm{s}\right) \text {, } \\
16 \text { h photoperiod. }\end{array}$ \\
\hline Other lettuce types & n.a. & $\begin{array}{l}\text { Edney et al. (2006), Flandria type: } 0.029^{2} ; 22^{\circ} \mathrm{C}, 50 \% \mathrm{rh} 1200 \mathrm{ppm} \mathrm{CO} 2,300 \mu \mathrm{mol} /\left(\mathrm{m}^{2 \star} \mathrm{s}\right), 16 \mathrm{~h} \\
\text { photoperiod. Richards et al. (2004a), Flandria type: } 0.063 ; 25^{\circ} \mathrm{C}, 50 \% \mathrm{rh}, 1200 \mathrm{ppm} \mathrm{CO}_{2}, 300 \\
\mu \mathrm{mol} /\left(\mathrm{m}^{2 \star} \mathrm{s}\right), 16 \mathrm{~h} \text { photoperiod. }\end{array}$ \\
\hline Red Giant & 0.130 & No reference literature found \\
\hline Frizzy Lizzy & 0.107 & Meinen et al. (2018): 0.322; same environmental conditions, but 10 times higher plant density. \\
\hline Swiss Chard & 0.102 & Meinen et al. (2018): 0.377; same environmental conditions, but 10 times higher plant density. \\
\hline Arugula (initial light intensity) & 0.111 & \\
\hline Arugula (higher light intensity) & 0.188 & Meinen et al. (2018): 0.162; same environmental conditions. \\
\hline Mizuna & 0.194 & No reference literature found \\
\hline Other leafy greens & n.a. & $\begin{array}{l}\text { Fu et al. }(2016)^{1}: 0.100 ; 500 \mu \mathrm{mol} /\left(\mathrm{m}^{2 *} \mathrm{~s}\right) \text {, no values for temperature, } \mathrm{rh}, \mathrm{CO}_{2} \text { and photoperiod } \\
\text { given. }\end{array}$ \\
\hline Basil Dolly & 0.060 & No reference literature found \\
\hline Parsley & 0.062 & Meinen et al. (2018): 0.143; same environmental conditions, but 3 times higher plant density. \\
\hline Chives & 0.053 & Meinen et al. (2018): 0.052; same environmental conditions. \\
\hline Tomato F1 3496B & 0.046 & $\begin{array}{l}\text { Wang et al. (2019): 0.048; } 25^{\circ} \mathrm{C}, 70 \% \mathrm{rh}, 400 \mathrm{ppm} \mathrm{CO}, 250 \mu \mathrm{mol} /\left(\mathrm{m}^{2 \star} \mathrm{s}\right), 14 \mathrm{~h} \text { photoperiod. } \\
\text { Spencer et al. (2019): } 0.049 ; 22^{\circ} \mathrm{C}, 60 \% \mathrm{rh}, 1507 \mathrm{ppm} \mathrm{CO}_{2}, 324 \mu \mathrm{mol} /\left(\mathrm{m}^{2 \star} \mathrm{s}\right), 16 \mathrm{~h} \text { photoperiod. } \\
\text { Masuda et al. (2005): } 0.028 ; 330 \mu \mathrm{mol} /\left(\mathrm{m}^{2 \star} \mathrm{s}\right) \text {, no values for temperature, rh, } \mathrm{CO}_{2} \text { and photoperiod } \\
\text { given. Wheeler et al. (2008): } 0.075^{2} ; 26^{\circ} \mathrm{C}, 65-75 \% \mathrm{rh}, 1000-1200 \mathrm{ppm} \mathrm{CO}_{2}, 549-893 \\
\mu \mathrm{mol} /\left(\mathrm{m}^{2 \star} \mathrm{s}\right), 12 \mathrm{~h} \text { photoperiod. }\end{array}$ \\
\hline Tomato F1 1202 & 0.052 & \\
\hline Cucumber Picowell & 0.321 & $\begin{array}{l}\text { Fu et al. (2016): } 0.228^{3} ; 500 \mu \mathrm{mol} /\left(\mathrm{m}^{2 \star} \mathrm{s}\right) \text {, no values for temperature, } \mathrm{rh}, \mathrm{CO}_{2} \text { and photoperiod } \\
\text { given. }\end{array}$ \\
\hline Radish Raxe & 0.078 & $\begin{array}{l}\text { Meinen et al. (2018): 0.058; same environmental conditions. Edney et al. (2006): } 0.203^{4} ; 22^{\circ} \mathrm{C} \text {, } \\
50 \% \text { rh } 1200 \mathrm{ppm} \mathrm{CO}_{2}, 300 \mu \mathrm{mol} /\left(\mathrm{m}^{2 *} \mathrm{~s}\right), 16 \mathrm{~h} \text { photoperiod. }\end{array}$ \\
\hline Radish Lennox & 0.059 & \\
\hline Kohlrabi & 0.141 & $\begin{array}{l}\text { Masuda et al. (2005): 0.121; } 330 \mu \mathrm{mol} /\left(\mathrm{m}^{2 *} \mathrm{~s}\right) \text {, no values for temperature, } \mathrm{rh}, \mathrm{CO}_{2} \text { and photoperiod } \\
\text { given. }\end{array}$ \\
\hline
\end{tabular}

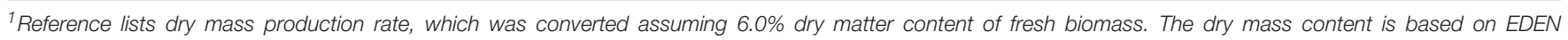
ISS measurements.

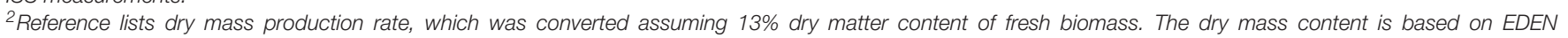
ISS measurements.

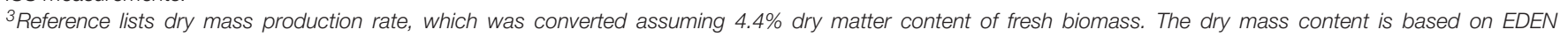
ISS measurements.

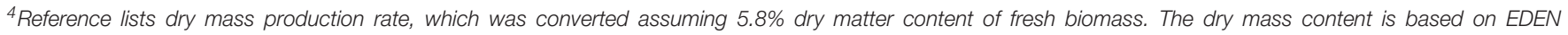
ISS measurements.

experiment campaign in Antarctica in 2018 to other experiments are summarized in Table $\mathbf{1 0 .}$

The FAOSTAT database, maintained by the United Nations Food Agriculture Organization, is a collection of yield values for a variety of commercially grown crops. This database can be filtered by crops and countries or regions of interest. Three crop categories similar to the EDEN ISS are found in the database: cucumbers/gherkins, tomatoes and lettuce/chicory. When looking on the FAOSTAT data for 2017 and setting the country to the Netherlands, the most effective producer of vegetables, one gets a yearly production of $68.97,50.84$, and $3.11 \mathrm{~kg} / \mathrm{m}^{2}$ for cucumbers/gherkins, tomatoes and lettuce/chicory, respectively. The EDEN ISS values for the 2018 season converted to a yearly production are $122.99 \mathrm{~kg} / \mathrm{m}^{2}$ cucumbers, $19.70 \mathrm{~kg} / \mathrm{m}^{2}$ tomatoes and $36.11 \mathrm{~kg} / \mathrm{m}^{2}$ lettuce. When comparing the values
EDEN ISS production is much higher for cucumbers and lettuce, but only around $40 \%$ for tomatoes. The difference in tomato production is most likely caused by the decision to grow less-effective dwarf tomato cultivars instead of normal sized high-productive tomatoes, while the much higher yield of cucumbers and lettuce can be explained by the absence of seasonal temperature and illumination changes which affect conventional greenhouse farming.

\section{SUMMARY}

During the 9 month long experiment campaign of the international EDEN ISS space greenhouse analog project in Antarctica a wide range of vegetables were cultivated. These 
crop species are also candidates for greenhouses on future human spaceflight missions. The plants were cultivated in a closed, controlled environment using an aeroponic system and LED illumination. The on-site operator in 2018 harvested more than $268 \mathrm{~kg}$ of fresh food from the $12.5 \mathrm{~m}^{2}$ cultivation area of the EDEN ISS greenhouse. A description of the cultivation conditions is part of this paper. Detailed production values (edible and inedible biomass) for each crop species are shown in this paper as well as dry biomass ratios. Comparisons of the EDEN ISS yield from 2018 to other experiments are made.

The EDEN ISS MTF is the newest and most state-of-theart space greenhouse analog experiment currently ongoing. The dataset presented in this paper can be of value to compare future experiments to and also for simulation and modeling efforts of space greenhouses. Furthermore, this first EDEN ISS biomass production data set states the beginning of a series of experimental seasons in Antarctica, which will continuously be recorded and published over the next years. One unique aspect of this research was the cultivation of all crops together in the same space under the same conditions. Although, this means that the conditions were not optimal for each cultivar, this is closer to how crop cultivation is going to be done in near-term space greenhouses, in which environmentally separated compartments for each crop are too costly and technically complex. This is in opposition to most laboratory experiments, in which crops are grown under optimal conditions.

\section{DATA AVAILABILITY STATEMENT}

The datasets generated for this study are available on request to the corresponding author.

\section{REFERENCES}

Bamsey, M., Zabel, P., Zeidler, C., Poulet, L., Schubert, D., Kohlberg, E., et al. (2014). "Design of a containerized greenhouse module for deployment to the Neumayer III Antarctic Station," in Proceedings of the 44th International Conference on Environmental Systems, Tucson.

Bamsey, M., Zabel, P., Zeidler, C., Vrakking, V., Schubert, D., Kohlberg, E., et al. (2016). "Early Trade-offs and top-level design drivers for antarctic greenhouses and plant production facilities," in Proceedings of the 46th International Conference on Environmental Systems, Piscataway, NJ.

Boscheri, G., Guarnieri, V., Iacopini, C., Locantore, I., Lamantea, M., Lobascio, C., et al. (2016). “The EDEN ISS rack-like plant growth facility," in Proceedings of the 46th International Conference on Environmental Systems, Piscataway, NJ.

Boscheri, G., Volponi, M., Lamantea, M., Lobascio, C., Schubert, D., and Zabel, P. (2017). "Main performance results of the EDEN ISS rack-like plant growth facility," in Proceedings of the 47th International Conference on Environmental Systems, New York, NY.

Bubenheim, D. L., Flynn, M. T., Lamparter, R., and Straight, C. L. (1994). "Remote sites as analogs for lunar and mars habitat pilot studies," in Proceedings of the 24th International Conference on Environmental Systems, Piscataway, NJ.

Dreschel, T. W., Knott, W. M., Prince, R. P., Sager, J. C., and Wheeler, R. M. (2018). "From project mercury to the breadboard project," in Proceedings of the 48th International Conference on Environmental Systems, Boston, MA.

\section{AUTHOR CONTRIBUTIONS}

$\mathrm{PZ}$ was the on-site operator of the EDEN ISS greenhouse in Antarctica during the experiment campaign, which means he was responsible for the plant cultivation and measurements, also worked on the materials and method part of the manuscript (section Materials and Methods), and on the data evaluation (section Results and Discussion). CZ, VV, MD, and DS were assisting the experiments from the mission control centre in Germany providing technical support and horticulture expertise. VV and DS provided input on the materials and method part of the manuscript (section Materials and Methods). DS was the project manager of EDEN ISS.

\section{FUNDING}

The EDEN ISS project has received funding from the European Union's Horizon 2020 Research and Innovation program under grant agreement No 636501.

\section{ACKNOWLEDGMENTS}

We are grateful for the work of all EDEN ISS project partners over the past 5 years. The project involved more than 60 scientists, engineers and administrative personnel from 14 partners in research, industry and education located in eight different countries.

\section{SUPPLEMENTARY MATERIAL}

The Supplementary Material for this article can be found online at: https://www.frontiersin.org/articles/10.3389/fpls.2020.00656/ full\#supplementary-material

Dueck, T., Frank, K., Esther, M., and Cecilia, S. (2016). "Choosing crops for cultivation in space," in Proceedings of the 46th International Conference on Environmental Systems, Berlin.

Edney, S. L., Richards, J. T., Yorio, N. C., Sisko, M. D., Stutte, G. W., and Wheeler, R. M. (2006). "Mixed vs. monoculture hydroponic production of salad crops at three CO2 Concentrations," in Proceedings of the 33rd PGRSA Annual Meeting, Boston, MA.

Fu, Y., Leyuan, L., Beizhen, X., Chen, D., Mingjuan, W., Boyang, J., et al. (2016). How to establish a bioregenerative life support system for long-term crewed missions to the moon or mars. Astrobiology 16, 925-936. doi: 10.1089/ast.2016. 1477

Gitelson, I. I., Lisovsky, G. M., and MacElroy, R. D. (2003). Manmade closed ecological systems. Earth space institute book series. New York, NY: Taylor \& Francis.

Masuda, T., Tako, Y., and Nitta, K. (2005). Matching between food supply and human nutritional requirements in closed ecology experiment facilities (CEEF). Eco Eng. 17, 61-66.

Meinen, E., Tom, D., Frank, K., and Cecilia, S. (2018). Growing fresh food on future space missions: environmental conditions and crop management. Sci. Hortic. 235, 270-278. doi: 10.1016/j.scienta.2018.03.002

Nitta, K. (2005). The mini-earth facility and present status of habitation experiment program. Adv. Space Res. 35, 1531-1538. doi: 10.1016/j.asr.2005. 03.100 
Patterson, R. L., Giacomelli, G. A., Kacira, M., Sadler, P. D., and Wheeler, R. M. (2012). Description, operation and production of the south pole food growth chamber. Acta Hortic. 952, 589-596. doi: 10.17660/ActaHortic.2012.952.75

Patterson, R. L., Giacomelli, G. A., and Sadler, P. D. (2008). "Resource and production model for the south pole food growth chamber," in In Proceedings of the 38th International Conference on Environmental Systems, Cham.

Richards, J. T., Edney, S. L., Yorio, N. C., Stutte, G. W., Cranston, N., Wheeler, R. M., et al. (2004a). "Effects of lighting intensity and supplemental CO2 on yield of potential salad crops for ISS," in Proceedings of the 34th International Conference on Environmental Systems, Virginia.

Richards, J. T., Yorio, N. C., Edney, S. L., Yunker, C. E., and Stutte, G. W. (2004b). “. Evaluating growth characteristics and total anthocyanin content in three cultivars of red romain-type lettuce (Lactuca sativa L.) in response to three lighting intensities," in Proceedings of the 31st PGRSA Annual Meeting, Piscataway, NJ.

Romeyn, M. W., Spencer, L. E., Massa, G. D., and Wheeler, R. M. (2019). “Crop readiness level (crl): a scale to track progression of crop testing for space," in Proceedings of the 49th International Conference on Environmental Systems, Amsterdam.

Santos, A., Virginia, I., Matthew, B., and Daniel, S. (2016). "A case study in the application of failure analysis techniques to Antarctic Systems: EDEN ISS," in Proceedings of the 2016 IEEE International Symposium on Systems Engineering (ISSE), Cambridge, MA, 1-7.

Schubert, D., Bamsey, M., Zabel, P., Zeidler, C., and Vrakking, V. (2018). "Status of the EDEN ISS greenhouse after on-site installation in Antarctica," in Proceedings of the 48th International Conference on Environmental Systems, Washington, DC.

Spencer, L. E., Hummerick, M. E., Stutte, G. W., Sirmons, T., Graham, T. G., Massa, G., et al. (2019). "Dwarf tomato and pepper cultivars for space crops," in Proceedings of the 49th International Conference on Environmental Systems, Boston, MA.

Vrakking, V., Bamsey, M., Zabel, P., Zeidler, C., Schubert, D., and Romberg, O. (2017). "Service Section design of the EDEN ISS project," in Proceedings of the 47th International Conference on Environmental Systems, New York, NY.

Wang, M., Chen, D., and Wanlin, G. (2019). Evaluation of the growth, photosynthetic characteristics, antioxidant capacity, biomass yield and quality of tomato using aeroponics, hydroponics and porous tube-vermiculite systems in bio-regenerative life support systems. Life Sci. Space Res. 22, 68-75. doi: 10.1016/j.lssr.2019.07.008
Wheeler, R. M. (2017). Agriculture for space: people and places paving the way. Open Agric. 2:1401. doi: 10.1515/opag-2017-0002

Wheeler, R. M., Mackowiak, C. L., Stutte, G. W., Yorio, N. C., Ruffe, L. M., Sager, J. C., et al. (2008). Crop productivities and radiation use efficiencies for bioregenerative life support. Adv. Space Res. 41, 706-713. doi: 10.1016/j.asr. 2007.06.059

Wheeler, R. M., Sager, J. C., Prince, R. P., Knott, W. M., Mackowiak, C. L., Stutte, G. W., et al. (2003). Crop Production for Advanced Life Support Systems: Observations From the Kennedy. Washington, DC: NASA.

Zabel, P., Bamsey, M., Schubert, D., and Tajmar, M. (2016a). Review and analysis of over 40 years of space plant growth systems. Life Sci. Space Res. 10, 1-16. doi: 10.1016/j.lssr.2016.06.004

Zabel, P., Bamsey, M., Zeidler, C., Vrakking, V., Johannes, B.-W., Rettberg, P., et al. (2015). "Introducing EDEN ISS - A european project on advancing plant cultivation technologies and operations," in Proceedings of the 45th International Conference on Environmental Systems, Bellevue.

Zabel, P., Bamsey, M., Zeidler, C., Vrakking, V., Schubert, D., and Romberg, O. (2017). "Future exploration greenhouse design of the EDEN ISS project," in Proceedings of the 47th International Conference on Environmental Systems, Charleston.

Zabel, P., Bamsey, M., Zeidler, C., Vrakking, V., Schubert, D., Romberg, O., et al. (2016b). "The preliminary design of the EDEN ISS mobile test facility - an antarctic greenhouse," in Proceedings of the 46th International Conference on Environmental Systems, Vienna.

Zeidler, C., Zabel, P., Vrakking, V., Dorn, M., Bamsey, M., Schubert, D., et al. (2019). The plant health monitoring system of the EDEN ISS space greenhouse in antarctica during the 2018 experiment phase. Front. Plant Sci. 10:1457. doi: $10.3389 /$ fpls.2019.01457

Conflict of Interest: The authors declare that the research was conducted in the absence of any commercial or financial relationships that could be construed as a potential conflict of interest.

Copyright (c) 2020 Zabel, Zeidler, Vrakking, Dorn and Schubert. This is an openaccess article distributed under the terms of the Creative Commons Attribution License (CC BY). The use, distribution or reproduction in other forums is permitted, provided the original author(s) and the copyright owner(s) are credited and that the original publication in this journal is cited, in accordance with accepted academic practice. No use, distribution or reproduction is permitted which does not comply with these terms. 